(c) American Dairy Science Association, 2004.

\title{
Sources of Variation in Rates of in Vitro Ruminal Protein Degradation ${ }^{1}$
}

\author{
G. A. Broderick, ${ }^{1}$ P. Udén, ${ }^{2}$ M. L. Murphy, ${ }^{2,} \dagger$ and A. Lapins ${ }^{2} \ddagger$ \\ ${ }^{1}$ Agricultural Research Service, USDA, \\ US Dairy Forage Research Center, Madison, WI 53706 \\ ${ }^{2}$ Kungsängen forskningscentrum, \\ Sveriges Lantbruksuniversitet, 75323 Uppsala, Sweden
}

\begin{abstract}
Rates and extents of ruminal protein degradation for casein, solvent soybean meal (SSBM), expeller soybean meal (ESBM), and alfalfa hay were estimated from net appearance of $\mathrm{NH}_{3}$ and total amino acids in in vitro media containing $1 \mathrm{~m} M$ hydrazine and $30 \mathrm{mg} / \mathrm{L}$ of chloramphenicol. Protein was added at $0.13 \mathrm{mg}$ of N/mL of medium, and incubations were conducted for 4 to $6 \mathrm{~h}$, usually with hourly sampling. Inocula were obtained from ruminally cannulated donor cows fed diets of grass silage or alfalfa and corn silages plus concentrates. Preincubation or dialysis of inocula was used to suppress background $\mathrm{NH}_{3}$ and total amino acids; however, preincubation yielded more rapid degradation rates for casein and SSBM and was used in subsequent incubations. Preincubation with added vitamins, VFA, hemin, or $\mathrm{N}$ did not alter protein degradation. Protein degradation rates estimated for SSBM, ESBM, and alfalfa were not different when computed from total $\mathrm{N}$ release or $\mathrm{N}$ release in $\mathrm{NH}_{3}$ plus total amino acids, regardless of whether amino acids were quantified using ninhydrin colorimetry or o-phthalaldehyde fluorescence. Accounting for the release of peptide-N also did not affect estimated degradation. However, casein degradation rates were more rapid when using total $\mathrm{N}$ release or accounting for peptide-N, indicating significant accumulation of small peptides during its breakdown. Rates also were more rapid with inocula from lactating cows versus nonlactating cows with lower feed intake. Protein degradation rates were different due to time after feeding: casein rate was more rapid, but SSBM and ESBM rates were slower with inocula obtained after feeding. Several characteristics of ruminal inoculum that influenced
\end{abstract}

\footnotetext{
Received June 10, 2003.

Accepted November 26, 2003.

Corresponding author: G. A. Broderick; e-mail: gbroderi@wisc.edu.

* Mention of any trademark or proprietary product in this paper does not constitute a guarantee or warranty of the product by the USDA or the Agricultural Research Service and does not imply its approval to the exclusion of other products that also may be suitable.

$\dagger$ Present address: Lantmannen Animal Feeds Division, PO Box 30192, Stockholm, S-10425, Sweden.

$\doteqdot$ Present address: Ministry of Agriculture, Riga, Latvia.
}

breakdown of the rapidly degraded protein casein did not appear to have direct effects on degradation of protein in soybean meal.

(Key words: protein degradation, rumen, inhibitor in vitro)

Abbreviation key: CAP = chloramphenicol, ESBM = expeller soybean meal, HS = hydrazine sulfate, IIV = inhibitor in vitro, $\mathbf{S S B M}=$ solvent soybean meal, $\mathbf{S R F}=$ strained ruminal fluid, TAA = total AA, $\mathbf{W R C}=$ whole ruminal contents.

\section{INTRODUCTION}

Rates and extents of ruminal degradation of feed proteins are required in a number of systems of ruminant ration formulation. Lack of reliable data on protein degradation can cause dairy farmers to under- or over-feed protein to their cattle. To avoid problems due to either error, routine methods that are both accurate and rapid are needed to allow timely characterization of protein degradation of common feeds. We have devoted a number of years to developing an inhibitor in vitro (IIV) method for assessing protein degradation (Broderick, 1978, 1987). With this approach, substrate-limiting amounts of protein (i.e., under first-order conditions) are incubated with ruminal inocula containing metabolic inhibitors to obtain quantitative recovery of breakdown products. Degradation rate $\left(\mathrm{k}_{\mathrm{d}}\right)$ is derived from the time-course of $\mathrm{N}$ appearance as total free AA (TAA) plus $\mathrm{NH}_{3}$. Extent of degradation is computed with this rate and an assumed ruminal solids passage rate $\left(\mathrm{k}_{\mathrm{p}}\right)$, typically $0.06 / \mathrm{h}$, from the ratio: $\mathrm{k}_{\mathrm{d}} /\left(\mathrm{k}_{\mathrm{d}}+\mathrm{k}_{\mathrm{p}}\right)$ (Waldo et al., 1972). This IIV procedure successfully predicted differences in milk and protein yield of cows fed solvent and expeller soybean meal (Broderick et al., 1990), characterized the ruminal degradability of different species of legume forages (Broderick and Albrecht, 1997) and several protein concentrates (England et al., 1997), identified the optimal extent of heating required for protecting protein in roasted soybeans (Faldet and Satter, 1991) and served as the basis of a solubility test (Hsu and Satter, 1995) and a near infrared spectromet- 
ric calibration (Tremblay et al., 1996) to estimate protein degradability in roasted soybeans.

Degradability estimates have varied considerably among IIV incubations run on different days using inocula from the same donor animals fed the same diets; this has necessitated greater replication, both within and among incubations. Understanding and controlling sources of variation could reduce the number of required replicate incubations and improve reliability of estimates of protein degradation. The objectives of the studies reported here were to use typical soybean meals, alfalfa hay, and a rapidly degraded standard protein (casein) to: 1) compare different methods for reducing background concentrations of $\mathrm{NH}_{3}$ and TAA in IIV inocula; 2) assess whether $\mathrm{NH}_{3}$ and TAA release is a reliable measure of protein degradation; and 3) quantify the effects of diet, level of intake, and related factors on observed degradation rates.

\section{MATERIALS AND METHODS}

\section{Locations and Donor Animals}

Experiments were conducted at both Uppsala, Sweden, and Madison, Wisconsin. Inocula were obtained from donor cows (Swedish Red or Holstein Friesian) surgically fitted with 10-cm ruminal cannulae (Bar Diamond; Parma, ID). Surgical care and general maintenance of the animals followed IACUC requirements at both locations. In most experiments, donors were milking cows fed lactation diets based on either grass silage plus concentrate (a mixture of barley, oats, sugarbeet pulp, rapeseed meal, soybean meal, and vitamins and minerals) in Sweden or on alfalfa silage and corn silage plus concentrate (a mixture of rolled high moisture corn, soybean meal, and vitamins and minerals) in Wisconsin. The Swedish lactation diet averaged $17 \% \mathrm{CP}$ and $1.60 \mathrm{Mcal} \mathrm{NE} / \mathrm{kg} \mathrm{DM}$ (computed at $3 \times$ maintenance; NRC, 2001), and the Wisconsin diet averaged $16.5 \% \mathrm{CP}$ and $1.60 \mathrm{Mcal} \mathrm{NE} / \mathrm{kg} \mathrm{DM}$ (computed at $3 \times$ maintenance; NRC, 2001). In one experiment conducted in Sweden, feed intake of donor animals was measured when inocula were collected from 2 cows fed the lactation diet ad libitum and 2 nonlactating cows restricted to only grass silage averaging $11 \% \mathrm{CP}$ and $1.26 \mathrm{Mcal}$ $\mathrm{NE}_{\mathrm{L}} / \mathrm{kg} \mathrm{DM}$ (computed at $1 \times$ maintenance; NRC, 2001). In all of the other experiments conducted in both Sweden and Wisconsin, donor animals were lactating cows fed ad libitum, but intake was not measured.

\section{Protein Sources}

The in vitro studies reported here were conducted with 5 different protein sources: casein (no. C-5890, Sigma Chemicals, St. Louis, MO), one sample of sol- vent-extracted soybean meal (SSBM), 2 different samples of expeller-extracted soybean meal (designated ESBM.1 and ESBM.2; West Central Coop., Ralston, IA), and one sample of alfalfa hay that had been fed in a previous experiment in which ruminal degradability had been estimated in vivo using N-15 as a microbial marker (Hristov and Broderick, 1996). Protein sources were ground with a cyclone mill (Udy Corp., Fort Collins, CO) fitted with a 1-mm screen. Protein composition data are in Table 1.

\section{Standard in Vitro Protocol}

In most studies conducted in both Sweden and Wisconsin, inocula were prepared using only preincubated strained ruminal fluid (SRF). Whole ruminal contents (WRC) were collected from beneath the fibrous mat in the rumen and filtered at the barn through 2 layers of cheesecloth into a warmed thermos bottle that had been flushed with $\mathrm{CO}_{2}$. This filtrate was transported to the laboratory and then filtered again through 4 layers of cheesecloth. In Wisconsin, four 10-mL aliquots were centrifuged $\left(10,000 \times g, 30 \mathrm{~min}, 4^{\circ} \mathrm{C}\right)$; pellets were dried ( $48 \mathrm{~h}$ in $60^{\circ} \mathrm{C}$ forced draft oven) and analyzed later for total N. Only duplicate aliquots were taken in Sweden. Because of the proximity of animal facilities at both locations, $<10$ min elapsed from initial collection of WRC until the preincubations were begun under $\mathrm{CO}_{2}$. Per liter of SRF, $8 \mathrm{~g}$ of maltose (Sigma no. M-2250), 4 $\mathrm{g}$ of xylose (Sigma no. X-1500), $4 \mathrm{~g}$ of soluble starch (Sigma no. S-2004), and $2.5 \mathrm{~g}$ of $\mathrm{NaHCO}_{3}$ were weighed into an Erlenmeyer flask and suspended with slow stirring in $100 \mathrm{~mL}$ of McDougall's buffer (McDougall, 1948) that had been freshly gassed with $\mathrm{CO}_{2}$. Four grams of citrus pectin (Sigma no. P-9135) was dispersed in 100 $\mathrm{mL}$ of water with heating and stirring and then added to the flask before flushing with $\mathrm{CO}_{2}$. Filtered SRF $(1000 \mathrm{~mL}$ ) and $0.2 \mathrm{~mL}$ of surfactant (Antifoam 204; Sigma no. A-6426) were added and the inoculum preincubated for 3 or $4 \mathrm{~h}$ by slow stirring in a $39^{\circ} \mathrm{C}$ bath. The flask headspace was continually flushed with a stream of $\mathrm{CO}_{2}$ during preincubation to maintain anaerobiosis. At $0 \mathrm{~h}$ and every hour, samples were taken for analysis of $\mathrm{NH}_{3}$ and TAA, and $\mathrm{pH}$ was measured; if $\mathrm{pH}$ was $<6.2, \mathrm{pH}$ was adjusted to 6.4 by slow addition of $3 \mathrm{~N} \mathrm{NaOH}$. Two solutions for inhibiting $\mathrm{NH}_{3}$ and TAA uptake were prepared by dissolving $72 \mathrm{mM}$ of hydrazine sulfate (HS; Sigma no. H-7394) and 2250 $\mathrm{mg} / \mathrm{L}$ of chloramphenicol (CAP; Sigma no. C-0378) in $39^{\circ} \mathrm{C}$ McDougall's buffer. Twenty-five milliliters of each, plus $0.293 \mathrm{~g}$ of mercaptoethanol (Sigma no. M6250 ), were added to give concentrations of $1.5 \mathrm{mM}$ $\mathrm{HS}, 45 \mathrm{mg}$ of CAP/L, and $3 \mathrm{~m} M$ mercaptoethanol. This inoculum was held at $39^{\circ} \mathrm{C}$ under a $\mathrm{CO}_{2}$ stream until 
Table 1. Composition of protein sources. ${ }^{1}$

\begin{tabular}{|c|c|c|c|c|c|c|}
\hline Protein source & Abbreviation & $\begin{array}{l}\mathrm{DM} \\
(\%)\end{array}$ & $\begin{array}{l}\text { Total N } \\
(\% \text { of } \mathrm{DM})\end{array}$ & $\begin{array}{l}\mathrm{ADIN} \\
(\% \text { of total } \mathrm{N})\end{array}$ & \multicolumn{2}{|c|}{$\begin{array}{c}\mathrm{TAA} / \mathrm{N}(\mathrm{CFA})^{2} \text { TAA/N }(\mathrm{FIA})^{2} \\
(\mu \mathrm{mol} / \mathrm{mg} \text { total } \mathrm{N})\end{array}$} \\
\hline Casein & - & 91.1 & 15.70 & 0.0 & 50.1 & 49.1 \\
\hline Solvent soybean meal & SSBM & 90.0 & 8.03 & 2.0 & 50.5 & 49.0 \\
\hline Expeller soybean meal \#1 & ESBM.1 & 92.1 & 8.16 & 2.3 & 51.2 & 46.2 \\
\hline Expeller soybean meal \#2 & ESBM.2 & 90.9 & 7.95 & 2.1 & 52.1 & 51.0 \\
\hline Alfalfa hay & - & 92.9 & 2.99 & 6.7 & 37.3 & 36.6 \\
\hline
\end{tabular}

dispensed at the start of the incubation (typically about $20 \mathrm{~min}$ ).

Incubations were conducted in either 50-mL polypropylene centrifuge tubes (Wisconsin) or $50-\mathrm{mL}$ roundbottom glass tubes (Sweden). In Wisconsin experiments, protein substrate equal to 1.9 to $2.0 \mathrm{mg}$ of $\mathrm{N}$ (equivalent to 14.0 to $70 \mathrm{mg}$ of the protein sources studied, weighed to the nearest $0.1 \mathrm{mg}$ ) was added to each tube. Then $5 \mathrm{~mL}$ of warm $\left(39^{\circ} \mathrm{C}\right) \mathrm{McDougall}$ 's buffer was added to each tube to wet the proteins, tube headspace flushed with $\mathrm{CO}_{2}$, and tubes were stoppered, and held at $39^{\circ} \mathrm{C}$ for about 1-h prior to inoculation. Incubations were begun by dispensing $10 \mathrm{~mL}$ of inoculum/tube using either a repipet or a Cornwall repeating syringe. Two times these amounts were used in incubations conducted in Sweden, and inoculum was dispensed using a Cornwall syringe, but otherwise the same protocols were used. Four blank tubes containing all ingredients except protein substrate were used for each time point in each incubation. Final medium concentrations in the studies reported here were $1.0 \mathrm{~m} M \mathrm{HS}, 30 \mathrm{mg}$ of CAP/ L, $2 \mathrm{~m} M$ mercaptoethanol (to maintain reducing conditions), and $0.13 \mathrm{mg} / \mathrm{mL}$ of protein- $\mathrm{N}$ from each source. Immediately after inoculating, tube headspace was flushed with $\mathrm{CO}_{2}$, tubes were capped with Bunsen valves, swirled, and incubated at $39^{\circ} \mathrm{C}$ in a warm room (Wisconsin) or a water bath (Sweden). Mixing was accomplished using a wrist-arm shaker at 150 cycles/min (Wisconsin) or by hand swirling at 1-h intervals (Sweden). A preliminary study in Sweden showed that mixing tube contents every hour yielded the same degradation rates as continuous shaking. Incubations were run from 0 to $4 \mathrm{~h}$, with hourly sampling in most studies. In Sweden, incubations were killed by transferring 1-mL aliquots of medium to $1.5-\mathrm{mL}$ centrifuge tubes containing $0.1 \mathrm{~mL}$ of $55 \% \mathrm{wt} / \mathrm{vol}$, TCA (final sample concentration of $5 \% \mathrm{wt} / \mathrm{vol})$. Killed samples were immediately capped and mixed by inversion, then placed on ice for $30 \mathrm{~min}$ before centrifuging $(10 \mathrm{~min}$ at $17,700 \times \mathrm{g})$. In Wisconsin, incubations were killed by adding $1.25 \mathrm{~mL}$ of $65 \% \mathrm{wt} / \mathrm{vol}$, TCA to the entire $15 \mathrm{~mL}$ of medium in each tube. Tube contents were mixed immediately by swirling and placed on ice for $30 \mathrm{~min}$, and then about $4 \mathrm{~mL}$ of sample was transferred to $12-\times 75$-mm plastic tubes and centrifuged ( $15 \mathrm{~min}$ at $15,300 \times g)$. Supernatants were either held at $5^{\circ} \mathrm{C}$ until analyzed for degraded-N later the same day or stored at $-18^{\circ} \mathrm{C}$ for later analysis. All incubation experiments were replicated twice.

\section{Computation of Rate and Extent of Degradation}

Fractions degraded (FD) and fractions undegraded (FUD) at each time-point were computed using the equations:

$$
\begin{aligned}
& \mathrm{FD}=\text { degraded-N/protein- } \mathrm{N} \\
& \mathrm{FUD}=1-\mathrm{FD},
\end{aligned}
$$

where degraded-N was the net release of $\mathrm{N}$ in $\mathrm{mg} / \mathrm{tube}$ detected as $\mathrm{NH}_{3}$ and TAA and protein-N was the total $\mathrm{N}$ in $\mathrm{mg} /$ tube added from each protein source. Degraded-N released as $\mathrm{NH}_{3}$ and TAA in TCA supernatants was computed using the equation:

$$
\begin{gathered}
\text { degraded-N, mg }=\left\{\left(\left[\mathrm{NH}_{3}\right]_{\text {prot }}-\left[\mathrm{NH}_{3}\right]_{\text {blank }}\right) \times 0.0140067\right. \\
\left.+\left([\mathrm{TAA}]_{\text {prot }}-[\mathrm{TAA}]_{\text {blank }}\right) /(\mathrm{TAA} / \mathrm{N})\right\} \times \text { Vol }
\end{gathered}
$$

where $\left[\mathrm{NH}_{3}\right]_{\text {prot }}$ and $\left[\mathrm{NH}_{3}\right]_{\text {blank }}$ and $[\mathrm{TAA}]_{\text {prot }}$ and [TAA $]_{\text {blank }}$ were $\mathrm{NH}_{3}$ and TAA concentrations in $\mathrm{mM}$ $(\mu \mathrm{mol} / \mathrm{mL})$ in, respectively, protein-containing and blank tubes, 0.0140067 was the $\mathrm{NH}_{3}-\mathrm{N}$ constant (mg of $\mathrm{N} / \mu \mathrm{mol}$ of $\mathrm{NH}_{3}$ ), TAA/N was the ratio of TAA (after HCl-hydrolysis) to total $\mathrm{N}$ ( $\mu \mathrm{mol} / \mathrm{mg}$ of $\mathrm{N}$ ) in the proteins studied (a mean of 50 was used for casein, SSBM, and ESBM and 37 was used for alfalfa hay; Table 1), and Vol was the total tube volume in milliliters. The TAA released by HCl-hydrolysis were assumed to represent all of the degradable $\mathrm{N}$ in each protein substrate.

Rates of ruminal protein degradation $\left(\mathrm{k}_{\mathrm{d}}\right)$ were computed by fitting FUD data to a single exponential model by: 1) linear regression on time of ln FUD at each time $(0,1,2,3$, and $4 \mathrm{~h})$; or 2$)$ using ln FUD only at time = $0 \mathrm{~h}\left(\mathrm{FUD}_{0}\right)$ and time $=4 \mathrm{~h}\left(\mathrm{FUD}_{4}\right)$ from the equation: 
Degradation Rate $\left(\mathrm{k}_{\mathrm{d}}\right), / \mathrm{h}=\left[\ln \left(\mathrm{FUD}_{4}\right)-\ln \left(\mathrm{FUD}_{0}\right)\right] / 4$.

The potentially degradable fraction of total CP (fraction B) was computed using the equation:

$$
\text { fraction } \mathrm{B}, \%=\left(\mathrm{FUD}_{0}\right) \times 100 \text {. }
$$

A correction for undegradable protein was not used because acid-detergent insoluble-N (ADIN), which ranged from 0 (casein) to $6.4 \%$ of total $\mathrm{N}$ (alfalfa hay), had only negligible effects on estimates of degradation rate and escape. Extents of ruminal protein escape were computed (Waldo et al., 1972):

$$
\text { ruminal protein escape, } \%=\mathrm{B} \times\left[\mathrm{k}_{\mathrm{p}} /\left(\mathrm{k}_{\mathrm{d}}+\mathrm{k}_{\mathrm{p}}\right)\right] \text {, }
$$

where $k_{\mathrm{p}}$, the ruminal passage rate, was set equal to $0.06 / \mathrm{h}$.

\section{Chemical Analyses}

Protein substrates were analyzed for total $\mathrm{N}$ by combustion assay (Leco FP-2000; Leco Instruments, Inc., St. Joseph, MI) in Wisconsin, for DM at $105^{\circ} \mathrm{C}$ (AOAC, 1980), and acid detergent insoluble-N (Van Soest et al., 1991). Proteins were hydrolyzed for $24 \mathrm{~h}$ at $105^{\circ} \mathrm{C}$ in sealed vials under a $\mathrm{N}_{2}$ atmosphere in $6 \mathrm{~N} \mathrm{HCl}$ containing $0.1 \% \mathrm{wt} / \mathrm{vol}$, phenol (Mason et al., 1979) using a ratio of 1-mg sample $\mathrm{N} / 5 \mathrm{~mL}$ of acid (Block and Weiss, 1956). After hydrolysis, samples were cooled, $\mathrm{HCl}$ was removed by vacuum evaporation, and the residues were redissolved in $0.1 \mathrm{~N} \mathrm{HCl}$. Both protein hydrolysates and TCA supernatants from preincubations and in vitro incubations in all Swedish studies and some Wisconsin studies were analyzed for $\mathrm{NH}_{3}$ and TAA using phenolhypochlorite and ninhydrin colorimetric assays adapted to continuous-flow analysis as described earlier (Broderick and Kang, 1980; Broderick, 1987), except with a sample rate of $60 / \mathrm{h}$. Assays for $\mathrm{NH}_{3}$ and TAA adapted to flow-injection analysis (Lachat Quick-Chem 8000 FIA; Zellweger Analytical, Milwaukee, WI) were used in the balance of Wisconsin studies. Flow-injection $\mathrm{NH}_{3}$ determination was also by phenol-hypochlorite assay (Lachat method 18-107-06-1- A); however, TAA were determined using a fluorimetric procedure based on reaction with $o$-phthalaldehyde (Roth, 1971). Leucine was the standard in both TAA assays; thus, TAA concentrations were expressed in Leu equivalents in all samples. Concentrations of TAA in HCl-hydrolysates of all proteins averaged 48 (range 37 to 52 ) $\mu \mathrm{mol} / \mathrm{mg}$ of total $\mathrm{N}$ by ninhydrin assay at both locations and 46 (range 37 to 51 ) $\mu \mathrm{mol} / \mathrm{mg}$ of total $\mathrm{N}$ by $o$-phthalaldehyde. The ratio for alfalfa hay was substantially lower than for the other proteins, and the overall mean by both methods, excluding alfalfa, was 49.9. A value of 50 $\mu \mathrm{mol} / \mathrm{mg}$ of total $\mathrm{N}$ was used in computations of FD for all proteins, except alfalfa hay, for which the mean of $37 \mu \mathrm{mol} / \mathrm{mg}$ of total $\mathrm{N}$ was used. The TCA supernatants also were analyzed in one study for total $\mathrm{N}$ by combustion assay (Mitsubishi TN-05 Nitrogen Analyzer; Mitsubishi Chemical Corp., Tokyo, Japan) and in a second study for total peptide concentration using a fluorescamine assay conducted at pH 6.2 (Broderick et al., 1988). Pellets from high-speed centrifugation of aliquots of inocula (prior to preincubation or dialysis) were analyzed for DM ( $48 \mathrm{~h}$ in $60^{\circ} \mathrm{C}$ forced draft oven) and total N [by a fully automated Kjeldahl procedure (Technicon, Solna, Sweden) in Sweden and by Leco combustion assay in Wisconsin].

\section{Experimental Studies}

Inoculum pretreatment. A series of trials was conducted in Wisconsin to assess methods of pretreating ruminal inoculum to enhance activity and reduce runto-run variation in estimated degradation. One study compared dialysis to preincubation of ruminal inocula prepared as described by Craig et al. (1984) to increase numbers of particle-associated microbes. Inocula were prepared by squeezing WRC through 2 layers of cheesecloth to obtain a given volume of SRF and then washing the remaining solids 4 times with a total volume of McDougall's buffer approximately equal to the original volume of SRF. The SRF plus solids-wash were mixed, filtered through 4 layers of cheesecloth, and then subsampled for determination of DM and $\mathrm{N}$ content of highspeed pellets. The McDougall's buffer used to wash ruminal solids had been just flushed with $\mathrm{CO}_{2}$ and was supplemented with an additional $0.125 \mathrm{~mol} / \mathrm{L}$ each of mono- and dibasic sodium phosphate to enhance its buffering capacity. A portion of the filtered SRF plus solids wash was poured into cellophane dialysis tubing (10,000 molecular weight cut-off; type T-4, $28.6 \mathrm{~mm}$ diam.; no. 21-152-14, Fisher Scientific, Itasca, IL), the headspace flushed with $\mathrm{CO}_{2}$ and dialyzed in a covered bath of $0.9 \%$, wt/vol, saline for $2 \mathrm{~h}$ in a $39^{\circ} \mathrm{C}$ warm room. The ratio of volumes of inoculum: saline was about 1:50. Contents of dialysis tubing were mixed by inversion every 30 min. Rate of $\mathrm{NH}_{3}$ disappearance during dialysis was determined in one study. After dialysis, inoculum was transferred to a flask and held under $\mathrm{CO}_{2}$ at $39^{\circ} \mathrm{C}$ until addition of inhibitors. A second portion of the remaining inoculum was preincubated under $\mathrm{CO}_{2}$ for $3 \mathrm{~h}$ with $2.5 \mathrm{~g} / \mathrm{L}$ each of glucose, sucrose (food grade), maltose, and soluble starch using slow stirring in a $39^{\circ} \mathrm{C}$ bath. At the end of the preincubation, the $\mathrm{pH}$ was checked and adjusted to 6.4 by slow addition of $3 \mathrm{~N}$ $\mathrm{NaOH}$. Solutions containing $60 \mathrm{~m} M$ HS $1800 \mathrm{mg}$ of 
$\mathrm{CAP} / \mathrm{L}$, and $10 \%$, wt/vol, maltose were prepared in $39^{\circ} \mathrm{C}$ McDougall's buffer and added as described to give 1.5 $\mathrm{m} M \mathrm{HS}, 45 \mathrm{mg}$ of CAP/L, and $0.5 \% \mathrm{wt} / \mathrm{vol}$ of maltose. The same amounts of HS and CAP were added, but McDougall's buffer only replaced the maltose solution, in inocula prepared from preincubated inoculum. Both inocula were made $3 \mathrm{~m} M$ with mercaptoethanol, and incubations were begun within 20 min to determine degradation parameters of 4 proteins (casein, SSBM, ESBM.1, and alfalfa hay) using the standard in vitro protocol. Blank and plus-substrate TCA supernatants were analyzed for $\mathrm{NH}_{3}$ and TAA by continuous-flow analysis and computations were done as described above.

Two additional trials conducted in Wisconsin assessed the effects of preincubating the inocula enriched with particle-associated microbes with other nutrients. In one study, 4 inocula were preincubated: with or without a mixture of vitamins (Schaefer et al., 1980) plus VFA and hemin (Hespell and Bryant, 1981), formulated as described by Luchini et al. (1996), each with or without $2.5 \mathrm{mM} \mathrm{NH} \mathrm{NH}_{3}$ added as $\left(\mathrm{NH}_{4}\right)_{2} \mathrm{SO}_{4}$. In the second study, 4 inocula were preincubated: with or without 2 g/L of enzymatically hydrolyzed casein (Sigma no. C1026), each with or without $5.0 \mathrm{mM} \mathrm{NH}$ added as $\left(\mathrm{NH}_{4}\right)_{2} \mathrm{SO}_{4}$. Preincubations also were conducted for $3 \mathrm{~h}$. The inocula were prepared and degradation parameters determined as described in the study comparing preincubation with dialysis.

Method of quantifying protein degradation. Three different methods of measuring degraded $\mathrm{N}$ were compared in one study conducted in Wisconsin: degraded $\mathrm{N}$ determined as $\mathrm{NH}_{3}$ and TAA assayed by either continuous-flow or flow-injection analyses, or by total $\mathrm{N}$ analysis of TCA supernatants using combustion assay (Mitsubishi TN-05). These incubations were conducted with 4 proteins (casein, SSBM, ESBM.2, and alfalfa hay) using the standard in vitro protocol. Blank and plus-substrate TCA supernatants were split and submitted to the 3 methods of analysis to determine net $\mathrm{N}$ release and computation of degradation parameters were done as described.

Inoculum fractionation. One study conducted in Wisconsin examined inocula prepared from: A) a blend of SRF plus buffer extract from WRC followed by preincubation for $3 \mathrm{~h}$ with a total $20 \mathrm{~g} / \mathrm{L}$ of mixed carbohydrates plus $2.5 \mathrm{~g} / \mathrm{L}$ of $\mathrm{NaHCO}_{3}$ as described earlier; B) centrifugation $\left(10,000 \times \mathrm{g}, 30 \mathrm{~min}, 10^{\circ} \mathrm{C}\right)$ of inoculum A prior to preincubation; C) centrifugation $(10,000 \times g$, $30 \mathrm{~min}, 10^{\circ} \mathrm{C}$ ) of the $\mathrm{SRF}$ used to prepare inoculum $\mathrm{A}$ (mostly fluid-phase microbes only); or D) centrifugation $\left(10,000 \times g, 30 \mathrm{~min}, 10^{\circ} \mathrm{C}\right)$ of the WRC buffer extract used to prepare inoculum A (mostly particle-associated microbes only). Pellets from $\mathrm{B}, \mathrm{C}$, and $\mathrm{D}$ were resus- pended in volumes of McDougall's buffer to give net $\mathrm{A}_{600}$ (i.e., corrected for blank $\mathrm{A}_{600}$ ) in inocula $\mathrm{B}, \mathrm{C}$, and $\mathrm{D}$ that was equivalent to the net $\mathrm{A}_{600}$ in inoculum $\mathrm{A}$ before preincubation. These 4 inocula were used in incubations conducted with 3 protein substrates (casein, SSBM, and ESBM.2) using the standard in vitro protocol. Blank and plus-substrate TCA supernatants were split and analyzed for $\mathrm{NH}_{3}$ and TAA by flow-injection analysis, total $\mathrm{N}$ by combustion assay (Mitsubishi TN05), and for total peptide concentrations using a fluorescamine assay at pH 6.2 (Broderick et al., 1988). Under conditions of this method, fluorescence due to free AA is $\leq 5 \%$ of that for most di- and tripeptides. Tri-alanine was the peptide standard, and it was assumed that there were $3 \mathrm{~N} /$ molecule of peptide detected. These data were used to compute net $\mathrm{N}$ release and degradation parameters as described.

Level of intake and time after feeding. One study conducted in Sweden examined the effect on degradation rate of preparing inocula with SRF from cows fed at 2 levels of intake collected at 3 times after feeding. Donor animals were 2 milking cows fed the lactation diet with $17 \% \mathrm{CP}$ and $1.60 \mathrm{Mcal} \mathrm{NE}_{\mathrm{L}} / \mathrm{kg} \mathrm{DM}$ and 2 nonlactating cows fed only the grass silage with $11 \%$ $\mathrm{CP}$ and $1.26 \mathrm{Mcal} \mathrm{NE} / \mathrm{kg}$ DM. Lactating cows were fed ad libitum, and nonlactating cows were offered $9 \mathrm{~kg}$ $\mathrm{DM} / \mathrm{d}$; mean DMI was determined only over the $2 \mathrm{wk}$ of this study. Lactating cows were fed twice per day and nonlactating cows were fed once per day. Inocula were prepared using SRF obtained from the 4 donor animals at $0 \mathrm{~h}$ (just before feeding), 2 and $4 \mathrm{~h}$ after feeding. These inocula were analyzed, preincubated for $3 \mathrm{~h}$, and then used in incubations conducted with 3 protein substrates (casein, SSBM, and ESBM.1) using the standard in vitro protocol. Thus, there were 3 sets of incubations conducted using 4 different inocula, each of which was begun within 20 min of completion of the preincubation phase. Blank and plus-substrate TCA supernatants were analyzed for $\mathrm{NH}_{3}$ and TAA by continuous-flow analysis, and degradation parameters were determined as described above.

\section{Statistical Analysis}

Quadruplicate blank and duplicate protein-containing tubes each were assayed in duplicate for $\mathrm{NH}_{3}$ and TAA at each time-point in each incubation. Means from these assays were used to compute a net $\mathrm{N}$ release value for each protein replicate tube at each time-point by the methods detailed earlier. Protein degradation parameters computed from net release of degraded-N in the IIV system were statistically analyzed using the general linear model of SAS (1999-2000). Effects of inoculum pretreatments were assessed using a model in- 
cluding incubation run, replicate(run), protein substrate, inoculum pretreatment [dialysis vs. preincubation or nutrient source during preincubation (vitamins, hemin, plus minerals and $\mathrm{NH}_{3}$; enzymatically hydrolyzed casein and $\mathrm{NH}_{3}$ )], and protein $\times$ run and protein $\times$ pretreatment interactions. Effect of method of quantifying degradation was assessed using a model including incubation run, replicate(run), protein substrate, analytical method (assaying $\mathrm{NH}_{3}$ and TAA by continuous flow analysis or flow injection analysis, or total $\mathrm{N}$ assay), and protein $\times$ run and protein $\times$ method interactions. This model also was used to test the effect of method of inoculum fractionation. Effect of level of intake and time after feeding was assessed using a model including incubation run, replicate(run), protein substrate, level (low or high), time after feeding $(0,2$, or $4 \mathrm{~h}$ ), and protein $\times$ run, protein $\times$ level, protein $\times$ time, and level $\times$ time interactions. Replicate(run) was used as the error term in testing for significance of treatments and 2-way interactions in all models. Interaction terms were removed from models when $P \geq 0.25$. Trends were identified at $0.10 \leq P \leq 0.05$; differences were declared significant at $P<0.05$. When the $F$-test for a treatment was significant $(P \leq 0.05)$, mean separation was conducted by least significant difference at $\alpha=0.05$. Simple linear regression was used to assess relationships between variables described in Figures 1 to 4 .

\section{RESULTS AND DISCUSSION}

\section{Inoculum Pretreatment}

Decreasing $\mathrm{NH}_{3}$ and TAA backgrounds improves precision in the IIV procedure because extent of degradation is estimated from concentration differences between blank and protein-containing incubations. Moreover, high concentrations of protein degradation products in the medium may alter observed degradation rates due to end-product inhibition (Broderick and Cochran, 2000). Mean $\mathrm{NH}_{3}$ concentration in inocula obtained in this experiment was $13 \mathrm{mM}$ and may have been relatively high because ruminal digesta were taken after feeding. Preliminary work indicated that the fractional rate of $\mathrm{NH}_{3}$ disappearance while dialyzing ruminal inoculum against a 50-volume excess of saline averaged $-0.73 / \mathrm{h}$. Thus, dialysis should have reduced $\mathrm{NH}_{3}$ from 13.0 to about $3.0 \mathrm{mM}$ at $2 \mathrm{~h}$; mean $\mathrm{NH}_{3}$ in the inoculum after dialysis for $2 \mathrm{~h}$ was $3.7 \mathrm{~m} M$. Preincubation in this experiment was less effective in reducing the background; mean $\mathrm{NH}_{3}$ was still $6.9 \mathrm{mM}$ after $3 \mathrm{~h}$. This may have resulted from ineffective buffering. During extraction of particulate microbes from WRC, the inoculum was diluted 50\% with McDougall's buffer (containing $0.25 \mathrm{M}$ of added phosphate); how- ever, mean $\mathrm{pH}$ declined from 6.4 to 5.9 during the $3 \mathrm{~h}$ preincubation. The $\mathrm{NH}_{3}$ and TAA concentrations in the final incubation media (containing all components) at $0 \mathrm{~h}$ were, respectively, about 2.6 and $0.3 \mathrm{mM}$ lower with dialysis (Table 2).

Although less effective for reducing background, preincubation gave rise to more rapid protein degradation; mean degradation rate was $54 \%$ greater $(P=0.006)$ than when using media prepared from dialyzed inoculum (Table 2). As expected, the effect of protein source on rate and estimated ruminal escape was highly significant. However, there also was a protein $\times$ treatment interaction because preincubation increased degradation rate, and reduced estimated escape, for casein and SSBM but did not alter these parameters for ESBM.1 and alfalfa hay. Rates and escapes observed for casein using dialyzed inoculum were not different from those found for SSBM using preincubated inoculum. It should be noted that the ranking of the 4 proteins for both degradation parameters was the same, and all 4 proteins were significantly different from each other, within each method of inoculum preparation. Luchini et al. (1996) found no difference in degradation rates using stored frozen or lyophilized ruminal inocula whether it was undialyzed or dialyzed prior to preservation. This suggested that dialysis itself did not depress microbial activity. Microbial protein content of inocula pellets from the present experiment averaged $0.80 \mathrm{~g} / \mathrm{L}$ $(\mathrm{CV}=35 \%)$. Hall and Herejk (2001) observed an increase in microbial protein equivalent to $1 \mathrm{~g} / \mathrm{L}$ when they incubated strained ruminal inocula with sucrose only, but added in concentrations similar to the amount of total carbohydrates used in our trial. That microbial biomass may have as much as doubled during preincubation could explain why it gave more rapid protein degradation.

Fraction $\mathrm{B}\left(\mathrm{FUD}_{0}\right)$, the proportion of intact protein, was lower in alfalfa hay because an overall mean 7.3\% of total $\mathrm{N}$ was present as $\mathrm{NH}_{3}$ plus TAA in the original feed. Previously, other samples of this same hay were found to contain $9.3 \%$ of total $\mathrm{N}$ as $\mathrm{NH}_{3}$ plus TAA and $14 \%$ of total N as NPN (N soluble in TCA; Hristov and Broderick, 1996). Various levels of NPN in alfalfa hay have been reported (proportion of total N): 8\% (Broderick, 1995), 13\% (Lines and Weiss, 1996), 23\% (Peltekova and Broderick, 1996), and 23 to 29\% (NRC, 1996). Many factors, including drying rate, determine the amount of NPN formed before water content falls to the point where proteolysis ceases (Carpintero et al., 1979). The proportion of ADIN in total $\mathrm{N}$ was $6.4 \%$ in this hay. Recomputing degradation rate and escape assuming that ADIN was equivalent to undegraded protein (Peltekova and Broderick, 1996) yielded a degradation rate that was numerically larger $(0.063$ vs. $0.055 / \mathrm{h}$; Table 
Table 2. Effect of dialysis versus pre-incubation of in vitro inoculum on initial $\mathrm{NH}_{3}$ and total AA (TAA) concentrations and on parameters of protein degradation. ${ }^{1}$

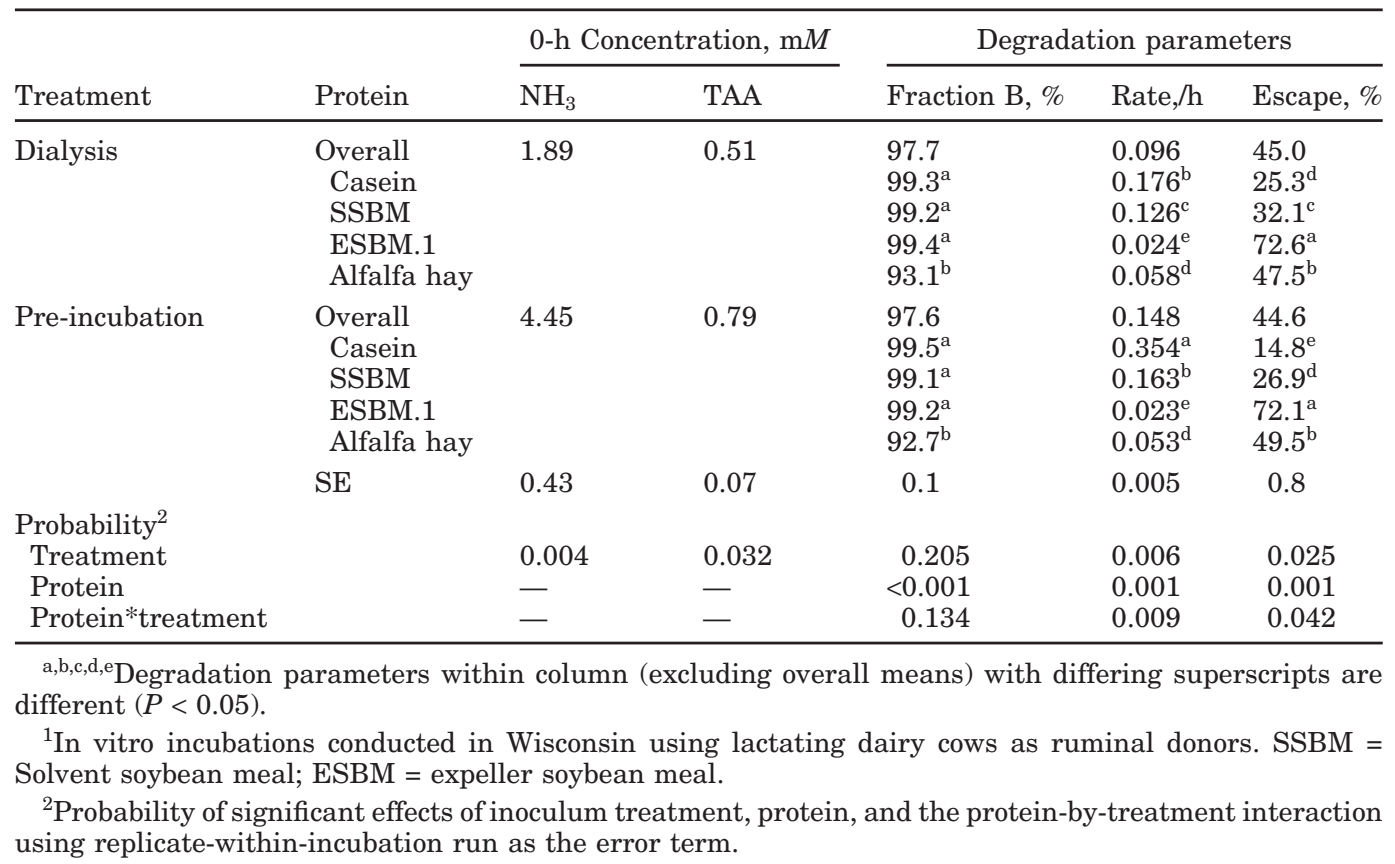

2) but not significantly different $(P=0.37)$. Moreover, estimated ruminal escape was virtually unchanged with or without use of an ADIN correction (49.0 vs. 48.5\%; Table 2). An ADIN correction also would not be needed if that fraction did not contribute to the TAA content of the proteins being studied (Table 1). However, Muscato et al. (1983) found a mean $62 \%$ of ADIN was accounted for as $\mathrm{N}$ in TAA in $\mathrm{HCl}$ hydrolysates from 5 feed proteins. It would be possible in this method to discount the TAA value of protein substrates for TAA$\mathrm{N}$ bound in ADIN. Degradation rates and escapes were not corrected for undegradable protein using the ADIN contents of either the alfalfa hay or the soybean meals (which averaged about $2 \% \mathrm{ADIN}$ in total $\mathrm{N}$ ) in any other results reported in this paper.

Obtaining inocula before feeding allowed experimentation to begin about 3-h earlier, but prefeeding inocula averaged only $5 \mathrm{mM} \mathrm{NH}$. If preincubation increased protein degradation by stimulating microbial growth, then limited nutrient supply could have reduced growth with inocula obtained prior to feeding. Preincubating inocula taken before feeding with $2.5 \mathrm{mM}$ added $\mathrm{NH}_{3}$ altered neither degradation rate nor escape (Table 3). Moreover, supplementing with a nutrient mixture of vitamins, VFA, and hemin (Luchini et al., 1996) had no overall effect on estimated rate or escape, and did not interact with added $\mathrm{NH}_{3}$, for the 4 proteins. A significant $(P=0.020)$ vitamin $\times$ protein interaction was detected for escape (Table 3 ). This resulted because the protein escape estimated for SSBM using inocula preincubated with this nutrient mixture was greater $(42 \%)$ than without (38\%), while there were no differences among inocula for the other protein substrates. Peptides and AA have been found to be more stimulatory than $\mathrm{NH}_{3}$ to growth of mixed ruminal microbes (Carro and Miller, 1999; Ranilla et al., 2001). However, preincubating with $2.0 \mathrm{mg} / \mathrm{L}$ of enzymatically hydrolyzed casein (250 $\mathrm{mg}$ of total N/L) appeared to reduce degradation rate; also, there was a tendency $(P=0.09)$ for $\mathrm{NH}_{3}$ addition at $5 \mathrm{~m} M(70 \mathrm{mg}$ of N/L) to suppress observed rate (Table 4). Although $\mathrm{NH}_{3}$ did not have a significant effect $(P \geq 0.108)$, adding casein hydrolysate increased background concentrations of both $\mathrm{NH}_{3}$ and TAA in the medium at $0 \mathrm{~h}$ (Table 4). A small but significant $(P=0.027) \mathrm{NH}_{3} \times$ protein interaction was noted for degradation rate. Protein degradation rates had the same pattern of significant differences as the overall means, except that the rate obtained for alfalfa hay using inocula preincubated with $\mathrm{NH}_{3}$ was not different from that for ESBM.1, while the rates were different from each other using control inocula. Added N, particularly peptides and AA, may have reduced apparent degradation rate via end-product inhibition (Broderick and Cochran, 2000).

Preincubating inocula with mixed carbohydrates was adopted as the standard technique for preparing IIV inoculum. Compared to the original protocol, a somewhat greater ratio of carbohydrates to $\mathrm{SRF}(20 \mathrm{~g} / \mathrm{L})$ was used, $\mathrm{NaHCO}_{3}$ was added to improve buffering, and $\mathrm{pH}$ was readjusted to 6.4 every hour during preincubation. 
Table 3. Effect of adding a mixture of vitamins, VFA, plus hemin (Luchini et al., 1996) or $\mathrm{NH}_{3}(2.5 \mathrm{~m} M$ ) during preincubation of in vitro inoculum on parameters of protein degradation. ${ }^{1}$

\begin{tabular}{|c|c|c|c|c|c|}
\hline Additive & Level & Protein & Fraction $\mathrm{B}, \%$ & Rate, /h & Escape, \% \\
\hline $\begin{array}{l}\text { Vitamins, VFA } \\
\text { + hemin }\end{array}$ & $\begin{array}{l}\text { No } \\
\text { Yes }\end{array}$ & & $\begin{array}{l}97.8 \\
97.5\end{array}$ & $\begin{array}{l}0.095 \\
0.090\end{array}$ & $\begin{array}{l}48.3 \\
49.5\end{array}$ \\
\hline $\mathrm{NH}_{3}$ & $\begin{array}{l}0 \\
2.5 \mathrm{~m} M \\
\mathrm{SE}\end{array}$ & & $\begin{array}{r}97.7 \\
97.6 \\
0.1\end{array}$ & $\begin{array}{l}0.091 \\
0.095 \\
0.009\end{array}$ & $\begin{array}{r}49.7 \\
48.1 \\
1.0\end{array}$ \\
\hline & & $\begin{array}{l}\text { Overall prote } \\
\text { Casein } \\
\text { SSBM } \\
\text { ESBM.1 } \\
\text { Alfalfa hay } \\
\text { SE }\end{array}$ & $\begin{array}{l}99.8^{\mathrm{a}} \\
99.3^{\mathrm{b}} \\
99.3^{\mathrm{b}} \\
92.2^{\mathrm{c}} \\
0.1\end{array}$ & $\begin{array}{l}0.216^{\mathrm{a}} \\
0.093^{\mathrm{b}} \\
0.013^{\mathrm{d}} \\
0.049^{\mathrm{c}} \\
0.009\end{array}$ & $\begin{array}{c}23.2^{\mathrm{d}} \\
39.9^{\mathrm{c}} \\
81.4^{\mathrm{a}} \\
51.0^{\mathrm{b}} \\
1.0\end{array}$ \\
\hline \multicolumn{6}{|l|}{ Probability $^{2}$} \\
\hline $\begin{array}{l}\text { Vitamins } \\
\mathrm{NH}_{3} \\
\text { Protein } \\
\text { Vitamin* } \mathrm{NH}_{3} \\
\text { Vitamin*Protein } \\
\mathrm{NH}_{3} * \text { Protein }\end{array}$ & & & $\begin{array}{r}0.162 \\
0.675 \\
<0.001 \\
0.273 \\
0.860 \\
0.906\end{array}$ & $\begin{array}{r}0.111 \\
0.136 \\
<0.001 \\
0.643 \\
0.095 \\
0.514\end{array}$ & $\begin{array}{r}0.128 \\
0.014 \\
<0.001 \\
0.114 \\
0.020 \\
0.303\end{array}$ \\
\hline
\end{tabular}

${ }_{\mathrm{a}, \mathrm{b}, \mathrm{c}, \mathrm{d}}$ Mean degradation parameters among overall means for protein sources with differing superscripts are different $(P<0.05)$.

${ }^{1}$ In vitro incubations conducted in Wisconsin using lactating dairy cows as ruminal donors. SSBM = Solvent soybean meal; ESBM = expeller soybean meal.

${ }^{2}$ Probability of significant effects of vitamin (vitamins, VFA, + hemin), $\mathrm{NH}_{3}$, protein source, and their two-way interactions, using replicate-within-incubation run as the error term.

Average hourly concentrations of $\mathrm{NH}_{3}$ and TAA in inocula from 8 preincubation studies are shown in Figure 1. Mean $\mathrm{NH}_{3}$ declined from 9.9 to $1.2 \mathrm{mM}$, and TAA from 1.6 to $1.0 \mathrm{~m} M$ over the course of $4 \mathrm{~h}$ when inoculum containing $80 \%$, vol/vol, SRF was preincubated with readily fermented carbohydrates. Similar results were

Table 4. Effect of adding $\mathrm{NH}_{3}$ or enzymatically hydrolyzed casein (CHE) during pre-incubation of in vitro inoculum on initial $\mathrm{NH}_{3}$ and total $\mathrm{AA}$ concentrations and on parameters of protein degradation. ${ }^{1}$

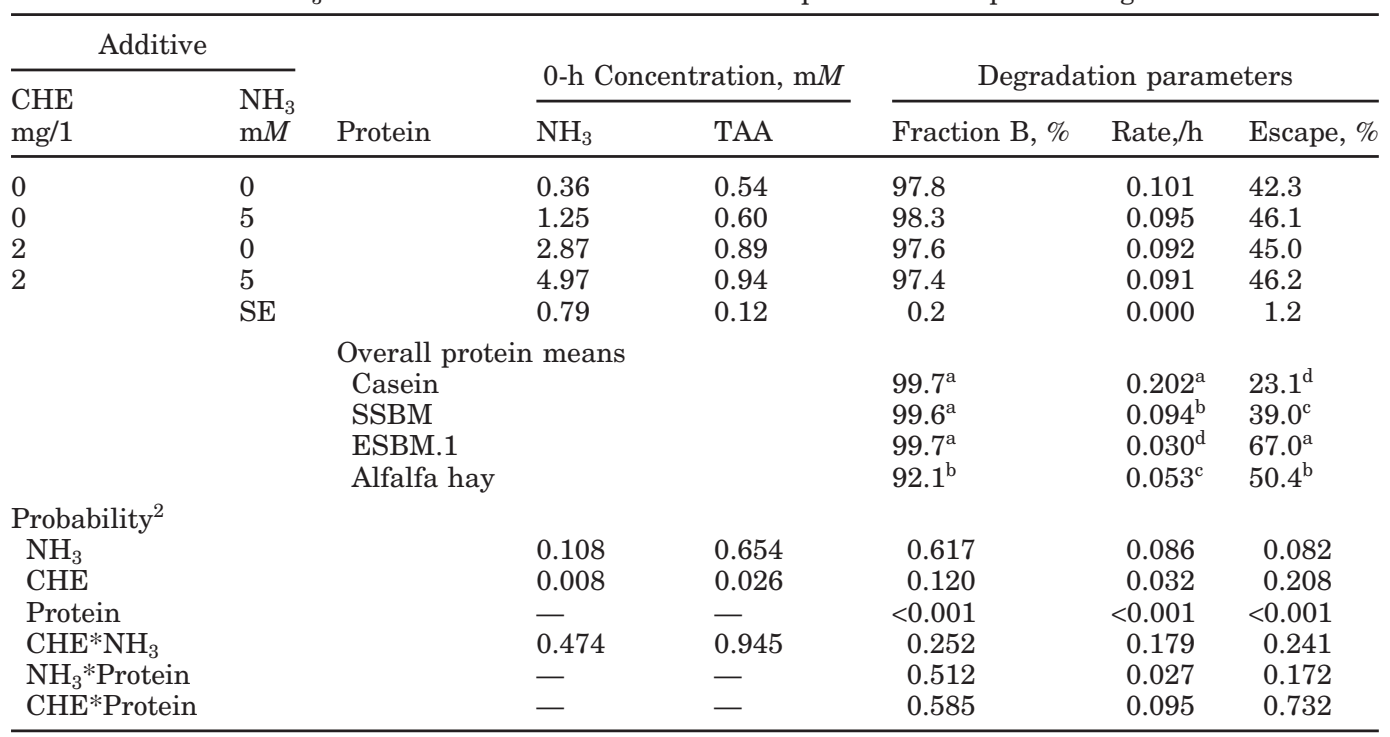

a,b,c,d Mean degradation parameters among overall means for protein sources with differing superscripts are different $(P<0.05)$.

${ }^{1}$ In vitro incubations conducted in Wisconsin using lactating dairy cows as ruminal donors. SSBM = Solvent soybean meal; ESBM = expeller soybean meal.

${ }^{2}$ Probability of significant effects of $\mathrm{CHE}$ and $\mathrm{NH}_{3}$ addition, protein source, and their 2 way interactions, using replicate-within-incubation run as the error term. 


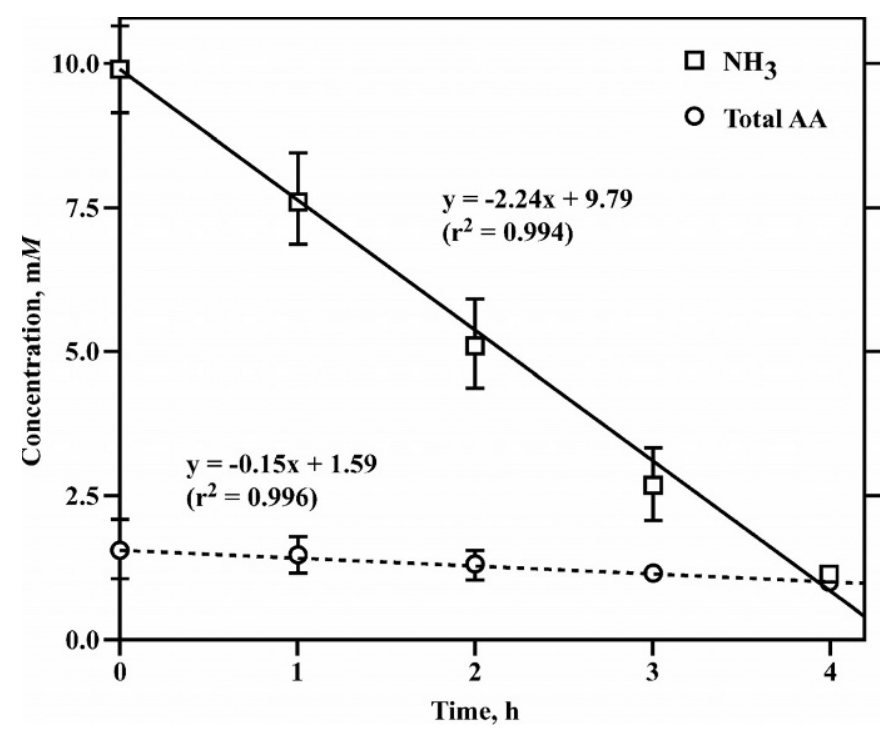

Figure 1. Regressions showing decline in $\mathrm{NH}_{3}$ and total AA concentrations during 4-h preincubations of ruminal inoculum with readily fermentable carbohydrates. Mean hourly concentrations from 8 preincubations conducted in Sweden with strained ruminal fluid (SRF) from both nonlactating (2 incubations) and lactating (6 incubations) cows after addition of (per liter of SRF): McDougall's buffer $(100 \mathrm{~mL})$, maltose $(8 \mathrm{~g})$, xylose $(4 \mathrm{~g})$, soluble starch $(4 \mathrm{~g})$, pectin $(4 \mathrm{~g}$ suspended in $100 \mathrm{~mL}$ of water), and $2.5 \mathrm{~g}$ of $\mathrm{NaHCO}_{3}$. Error bars are \pm 1 SEM

obtained using the inoculum prepared from SRF plus the McDougall's buffer extract from WRC, so long as $\mathrm{NaHCO}_{3}$ was added to buffer $\mathrm{pH}$. Decline in $\mathrm{NH}_{3}$ concentration was linear $\left(\mathrm{r}^{2}=0.994\right)$ at a rate of $-2.2 \mathrm{mM} /$ $\mathrm{h}$; the decrease in TAA concentration was slower $(-0.15$ $\mathrm{m} M / \mathrm{h})$ but also linear $\left(\mathrm{r}^{2}=0.994\right)$. Depending on initial concentration, preincubation for $3 \mathrm{~h}$ usually was sufficient to reduce inoculum $\mathrm{NH}_{3}$ to less than $1 \mathrm{mM}$, and that time was adopted for regular use.

\section{Method of Quantifying Protein Degradation}

Peptides are major intermediates in protein degradation (Wallace et al., 1999). Therefore, quantifying degraded protein from appearance of only $\mathrm{NH}_{3}$ and TAA may lead to underestimation of rate and extent of degradation. However, peptides also escape the rumen (Choi et al., 2002); thus, peptides may not constitute "degraded" protein. In this experiment, degradation was assessed from $\mathrm{NH}_{3}$ plus TAA appearance determined using the continuous-flow method (phenol-hypochlorite determination of $\mathrm{NH}_{3}$ and ninhydrin detection of TAA), using a more rapid flow-injection technique (phenolhypochlorite determination of $\mathrm{NH}_{3}$ but with an 0 phthalaldehyde-fluorimetric assay of TAA), or from total $\mathrm{N}$ analysis of the TCA-supernatants (Table 5). With one exception, there were no significant differences among proteins in degradable fraction $\mathrm{B}$ or in degradability estimates based on $\mathrm{NH}_{3}$ plus TAA using either continuous-flow or flow-injection analysis. This indicated that the flow-injection technique was just as reliable and would not yield biased results. However, there were significant method, protein, and method $\times$ protein interactions for estimates of fraction $\mathrm{B}$ because degraded protein in alfalfa hay at $0 \mathrm{~h}$ accounted for $29 \%$ of total N, versus only $7 \%$ by the other methods. This suggested that substantial amounts of TCA soluble-N were present as peptides in alfalfa hay. Previously, we estimated the NPN content of this hay at $14 \%$ of total N (Hristov and Broderick, 1996). Despite this effect, method of quantifying degraded protein did not significantly alter estimated degradation rate for alfalfa hay. However, SE for degradation rate in this study were 2 to 4 times greater than those in earlier experiments (Tables 2 to 4). This was due to the greater variation introduced by the total $\mathrm{N}$ assay. The smaller fraction B estimated by total $\mathrm{N}$ assay compensated for numerically slower degradation rates; thus, estimated escapes were similar among methods for alfalfa. Only the rates estimated for casein, the most rapidly degraded protein, were different due to assay method, indicating that there was accumulation of end-product not accounted for with $\mathrm{NH}_{3}$ plus TAA alone.

\section{Inoculum Fractionation}

Although casein is readily solubilized in ruminal fluid and rumen-like buffers, most of the $\mathrm{CP}$ in soybean meals and alfalfa, and many other feedstuffs, is bufferinsoluble and may be degraded principally by particleassociated microbes. Moreover, casein appears to give rise to substantial peptide accumulation during its degradation (Broderick and Craig, 1989). Inocula were prepared using the blend of SRF plus buffer extract from WRC by preincubating (A) or by centrifuging (prior to preincubation) to isolate microbes from the fluid plus particulate-phase (B), fluid-phase only (C), or particulate-phase only (D). Microbial pellets were resuspended in buffer to give $\mathrm{A}_{600}$ (a measure of microbial biomass) similar to inoculum A prior to preincubation. Degradation was computed from net release of $\mathrm{N}$ as $\mathrm{NH}_{3}$ plus TAA, with or without inclusion of peptide-N, or from net accumulation of total $\mathrm{N}$ in the TCA-supernatant. Effect of inoculum preparation differed among proteins within method of quantifying degradation rate (Table 6). Compared to inoculum A, casein rates estimated from only net $\mathrm{NH}_{3}$ plus TAA appearance were much slower using any of the other 3 inocula, and averaged only $44 \%$ of that with the preincubated control. Furthermore, casein degradation rates for $\mathrm{B}$ to $\mathrm{D}$ were not different from rates observed for SSBM with 3 of the 
Table 5. Effect of using three different methods of quantifying degraded protein on observed parameters of protein degradation. ${ }^{1}$

\begin{tabular}{llccc}
\hline Protein & Method $^{2}$ & Fraction B, $\%$ & Rate, /h & Escape, $\%$ \\
\hline Casein & CFA & $100.0^{\mathrm{ab}}$ & $0.233^{\mathrm{b}}$ & $20.6^{\mathrm{de}}$ \\
& FIA & $100.7^{\mathrm{a}}$ & $0.250^{\mathrm{ab}}$ & $20.1^{\mathrm{e}}$ \\
& Total N & $98.5^{\mathrm{ab}}$ & $0.286^{\mathrm{a}}$ & $17.2^{\mathrm{e}}$ \\
SSBM & CFA & $99.2^{\mathrm{ab}}$ & $0.121^{\mathrm{c}}$ & $33.0^{\mathrm{c}}$ \\
& FIA & $99.6^{\mathrm{ab}}$ & $0.129^{\mathrm{c}}$ & $32.0^{\mathrm{c}}$ \\
& Total N & $100.0^{\mathrm{ab}}$ & $0.152^{\mathrm{c}}$ & $29.0^{\text {cd }}$ \\
ESBM.2 & CFA & $99.5^{\mathrm{ab}}$ & $0.023^{\mathrm{d}}$ & $72.5^{\mathrm{a}}$ \\
& FIA & $99.5^{\mathrm{ab}}$ & $0.023^{\mathrm{d}}$ & $72.1^{\mathrm{a}}$ \\
& Total N & $97.4^{\mathrm{ab}}$ & $0.016^{\mathrm{d}}$ & $76.9^{\mathrm{a}}$ \\
Alfalfa hay & CFA & $92.9^{\mathrm{b}}$ & $0.035^{\mathrm{d}}$ & $58.7^{\mathrm{b}}$ \\
& FIA & $93.4^{\mathrm{b}}$ & $0.051^{\mathrm{d}}$ & $50.5^{\mathrm{b}}$ \\
& Total N & $70.6^{\mathrm{c}}$ & $0.012^{\mathrm{d}}$ & $58.7^{\mathrm{b}}$ \\
& SE & 2.5 & 0.017 & 2.8 \\
Probability & & & 0.456 \\
Method & & 0.005 & 0.499 & $<0.001$ \\
Protein & & $<0.001$ & $<0.001$ & 0.337 \\
Method*Protein & & 0.005 & 0.299 & \\
\hline
\end{tabular}

a,b,c,d,e Mean degradation parameters in columns with differing superscripts are different $(P<0.05)$.

${ }^{1}$ In vitro incubations conducted in Wisconsin using lactating dairy cows as ruminal donors. SSBM = solvent soybean meal; ESBM = expeller soybean meal.

${ }^{2}$ The 3 methods to quantify degraded protein were colorimetric assays of $\mathrm{NH}_{3}$ and TAA using continuous flow analysis (CFA), colorimetric $\mathrm{NH}_{3}$ assay and fluorimetric TAA assay using flow injection analysis (FIA), or total $\mathrm{N}$ assay on the TCA-supernatant (Total N).

${ }^{3}$ Probability of significant effects of method of quantifying degraded protein, protein source, and their 2 way interactions, using replicate-within-incubation run as the error term.

4 inocula tested. Accounting for peptide-N (based on fluorescamine assay; Broderick et al., 1988) reduced differences among inocula, with rates for $\mathrm{B}$ to $\mathrm{D}$ ranging from 64 to $86 \%$ of A. Casein rates for inocula B to D computed from total $\mathrm{N}$ release ranged from 82 to $88 \%$ of inoculum A. Rates determined for casein by these latter 2 methods all were more rapid than for SSBM. That accounting more completely for all degraded-N made rates more similar indicated that preincubated inoculum A was relatively more active in peptide breakdown to TAA and $\mathrm{NH}_{3}$. This suggested that an effect of preincubation was to increase numbers of Prevotella species because of their importance in peptide catabolism (Wallace et al., 1999). Overall, casein rate was not different when computed from $\mathrm{N}$ in $\mathrm{NH}_{3}$, TAA plus peptides, or by total $\mathrm{N}$, and both were more rapid than that obtained from $\mathrm{NH}_{3}$ plus TAA-N only. Thus, if small peptides may be considered as degraded protein, measurement of net release of only $\mathrm{NH}_{3}$ and TAA appeared to underestimate rate for the rapidly degraded protein casein. Mixed ruminal microbes can catabolize small peptides very rapidly (Broderick et al., 1988). The substantial quantities of peptides that appear to pass out of the rumen (Choi et al., 2002) may derive at least partly from intraruminal turnover of microbial protein (Wells and Russell, 1996) as well as from degradation of feed protein.
Effects were less dramatic for the 2 soybean meals (Table 6). Neither method of inoculum preparation nor method of quantifying degradation had any effect on degradation rates estimated for ESBM, the most slowly degraded protein. However, SSBM rates, regardless of method of quantitation, were more rapid using fluidphase microbes (C) than the sedimented, resuspended fluid plus particle-associated microbes (B). Rates with C were more rapid than with A for 2 of 3 assay methods. Rates obtained for SSBM using only particle-associated microbes (D) were only about half those obtained with inoculum $\mathrm{C}$. These results were surprising because about $80 \%$ of the total protein in SSBM is buffer insoluble (NRC, 1996). This suggested that enriching for particle-associated microbes was unimportant and that inocula based on SRF alone may yield satisfactory estimates of protein degradation rate for most feeds.

\section{Level of Intake and Time After Feeding}

Degradation rates may be more rapid using inocula from cows with higher feed intakes because of greater microbial biomass. Moreover, the greater microbial activity in preincubated media (Table 2 ) may have derived from increased microbial numbers. The effect of level of intake was assessed experimentally by comparing degradation rates (computed from accretion of $\mathrm{NH}_{3}$ and 
Table 6. Effects of fractionating inoculum and accounting for peptide contribution to degraded protein on observed rates of protein degradation. ${ }^{1}$

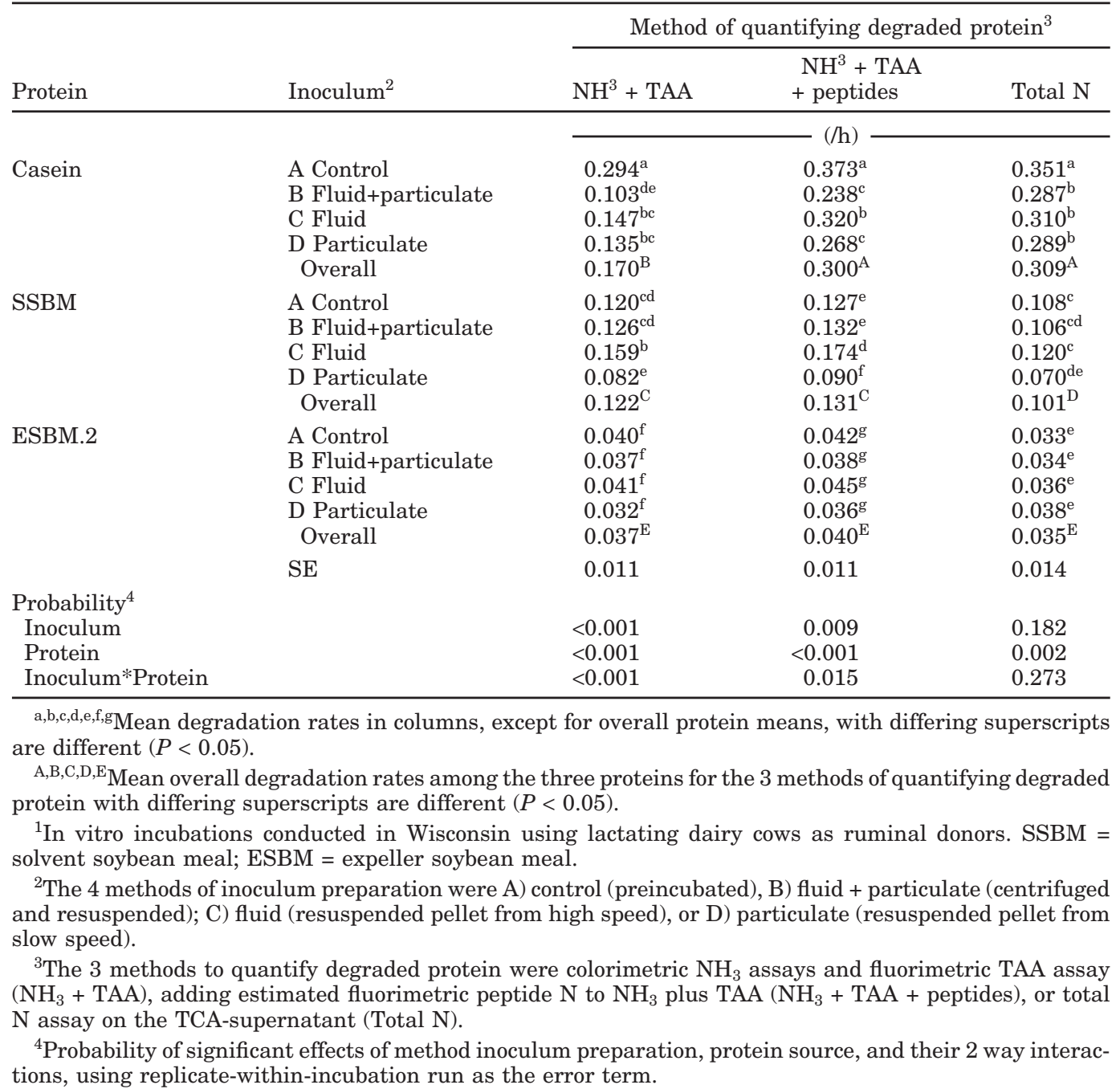

TAA) obtained using inocula from lactating cows consuming about $34 \mathrm{Mcal}$ of $\mathrm{NE}_{\mathrm{L}}$ per day to rates found using inocula from nonlactating cows eating about onethird as much energy (Table 7). Greater intake resulted in more rapid degradation for all 3 proteins, increasing rates by about one-third for SSBM and ESBM and nearly doubling that for casein (Table 7). However, a contradictory effect was observed for these proteins with time of digesta collection after feeding: estimated degradation rate increased for casein but declined for both SSBM and ESBM (Table 7). Because peptide accumulation may influence apparent casein degradation, but not that of the soybean meals, increased rates after feeding may result from greater peptide hydrolysis as well as enhanced microbial numbers and or proteolytic activity. There is increased microbial colonization of particulates in the rumen after feeding (Craig et al., 1987), and feeding may have reduced unattached organ- isms in the fluid-phase. Fluid-phase microbes appeared to be more active than particle-associated organisms in degrading SSBM, but not ESBM (Table 6). Rates of degradation were relatively slow in this study, even using inocula from lactating cows. Moreover, there were significant time $\times$ level interactions for all 3 proteins (Table 7). The interactions resulted because there was little change in rate with time after feeding with inocula from cows at maintenance; however, rate increased by about half (casein) or decreased by about one-third (SSBM and ESBM) from 0 to $4 \mathrm{~h}$ after feeding at the higher level of intake. Dietary protein content and intake also were greater in the lactating cows consuming greater amounts of DM and energy. Siddons and Paradine (1981) fed sheep diets consisting mostly of corn, timothy hay, barley, or alfalfa hay; CP intakes ranged from 63 (timothy) to 166 (alfalfa) g/d and digestible OM intakes ranged from 400 (timothy) to 600 (corn) g/d. 
Table 7. Effect of level of intake and time after feeding of obtaining inocula from donor animals on observed rates of protein degradation. ${ }^{1}$

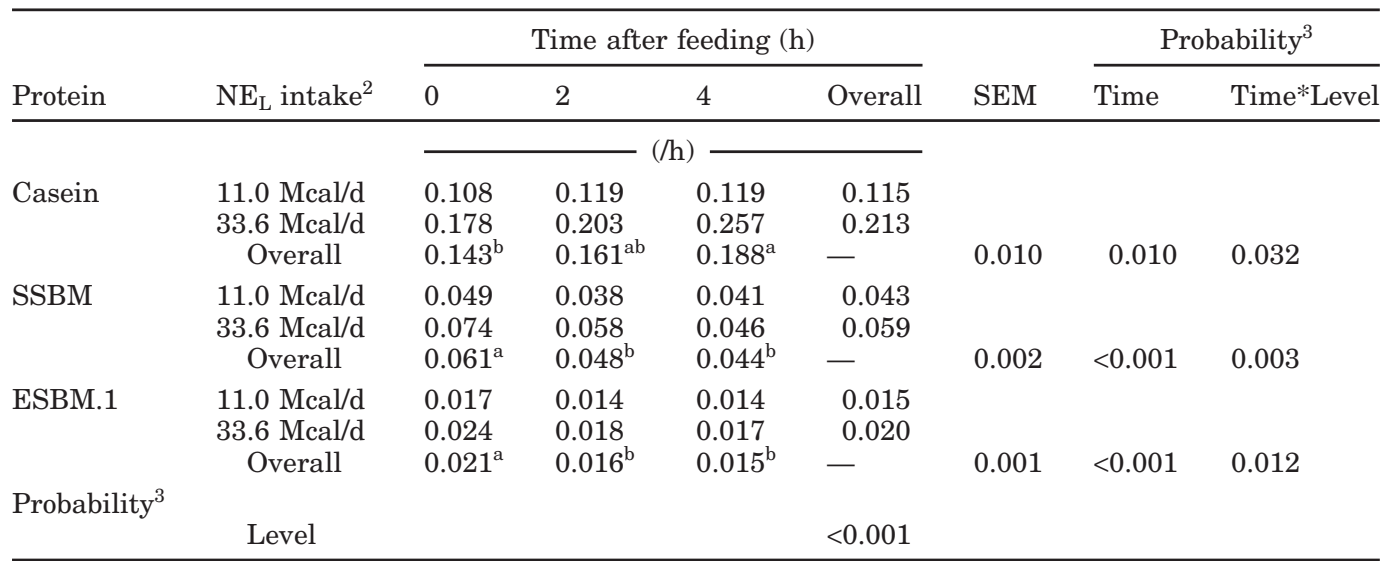

\footnotetext{
${ }^{a b}$ Mean overall degradation rates in rows having different superscripts are different $(P<0.05)$

${ }^{1}$ In vitro incubations conducted in Sweden. SSBM = solvent soybean meal; ESBM = expeller soybean meal.

${ }^{2}$ Mean DM and CP intakes of nonlactating and lactating cows were, respectively, 8.7 and $1.24 \mathrm{~kg} / \mathrm{d}$ and $21.0 \mathrm{~kg} / \mathrm{d}$ and $3.74 \mathrm{~kg} / \mathrm{d}$.

${ }^{3}$ Probability of significant effect, within protein souce, of time after feeding and the two-way time by level interaction, and of the overall effect of level of intake on observed degradation rate.
}

Proteolytic activity (measured as rate of casein hydrolysis to free AA) in ruminal fluid from these sheep was directly proportional to intake of digestible OM and apparently unrelated to dietary $\mathrm{CP}$ content or intake. Furchtenicht and Broderick (1987) reported similar results.

In an attempt to find some characteristic of the inoculum that may be related to degradation rate for these 3 proteins, we plotted observed rates against microbial $\mathrm{CP}$ or DM in the media (estimated using high-speed centrifugation). There was a strong correlation $\left(\mathrm{r}^{2}=\right.$ 0.81 ) between protein concentration at $0 \mathrm{~h}$ and casein degradation rate (Figure 2 ). The same correlations were found between casein rate and DM and protein content of the inoculum as collected $\left(\mathrm{r}^{2}=0.81\right)$ and after preincubation $\left(r^{2}=0.81\right)$. However, protein concentration of the medium was not correlated with degradation rates for SSBM $\left(r^{2}=0.09\right)$ or ESBM $\left(r^{2}=0.10\right)$. Moreover, there was little change in soybean meal rates over the range of protein concentrations at low feed intake and even a negative relationship between medium protein content and degradation rate $\left(\mathrm{SSBM}, \mathrm{r}^{2}=0.40\right.$; $\mathrm{ESBM}$, $\mathrm{r}^{2}=0.35$ ) using media derived from cows at high intake (Figure 2). Reduced degradation of SSBM and ESBM may not have been caused by some unknown effect that paralleled increased microbial biomass and numbers that followed eating. Other factors occurring with feeding (e.g., the attachment of fluid-phase organisms discussed above) may have reduced degradation of the soybean meals at the same time total microbial biomass was increasing. Furthermore, there was no relationship between casein degradation rate and rates obtained for either SSBM $\left(r^{2}=0.03\right)$ and ESBM $\left(r^{2}=0.02\right)$ (Figure 3). Clearly, several factors that influenced casein degra-

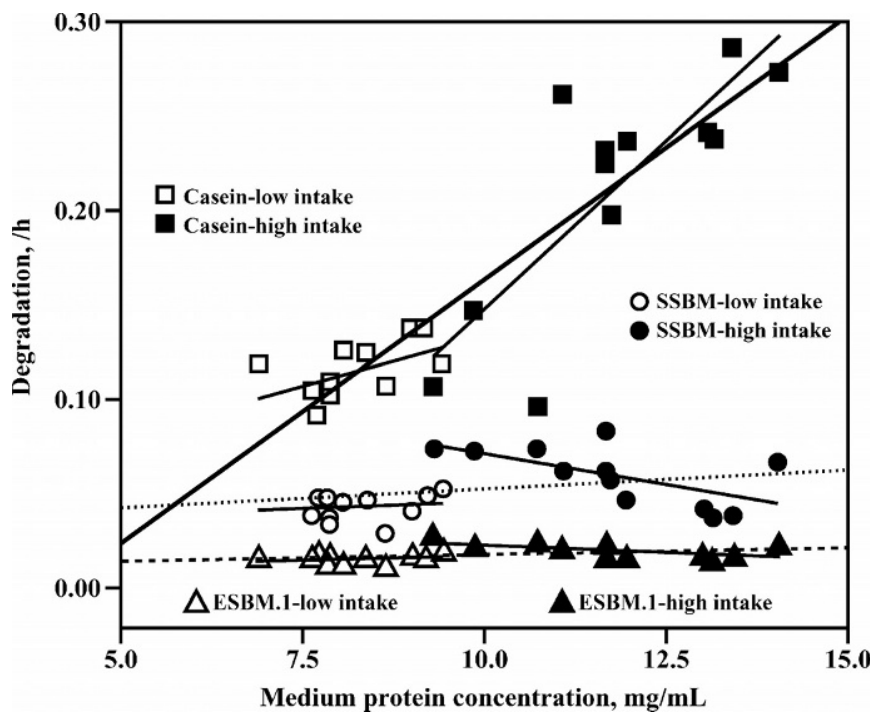

Figure 2. Regressions of degradation rates observed in Sweden for casein, solvent soybean meal (SSBM), and expeller soybean meal (ESBM.1) on $\mathrm{CP}(\mathrm{N} \times 6.25)$ concentrations in final media from incubations conducted using ruminal inocula from nonlactating cows fed at maintenance (open symbols) and from lactating cows fed at about $3 \times$ maintenance (closed symbols). Bold regression lines, for each protein over both levels of feed intake, yielded regressions of: $y=0.028 x-$ $0.115\left(\mathrm{r}^{2}=0.810\right)$ for casein; $\mathrm{y}=0.002 \mathrm{x}+0.032\left(\mathrm{r}^{2}=0.086\right)$ for SSBM; and $\mathrm{y}=0.001 \mathrm{x}-0.011\left(\mathrm{r}^{2}=0.099\right)$ for ESBM.1. The lighter regression lines represent the trends for each protein within each level of feed intake. 


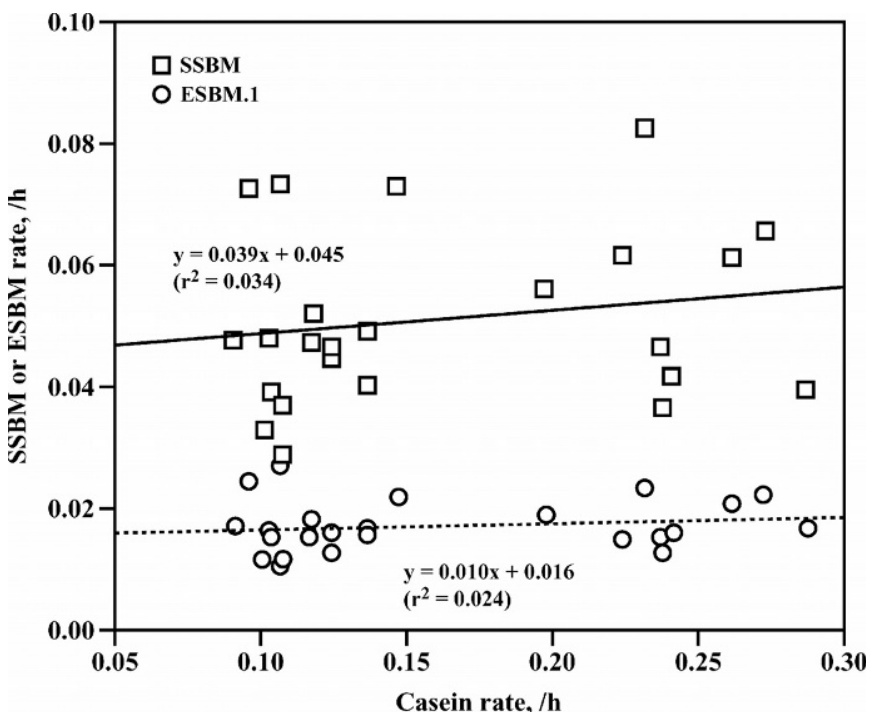

Figure 3. Regressions of degradation rates observed in Sweden for solvent soybean meal (SSBM) and expeller soybean meal (ESBM.1) on rates obtained for casein using ruminal inocula from both nonlactating cows fed at maintenance and lactating cows fed at about $3 \times$ maintenance.

dation in these studies were distinct from those affecting soybean meals. Degradative activity toward casein appeared not to be directly related to breakdown of the other 2 proteins.

An interesting finding was the strong positive correlation between TAA concentration in the medium at 0 $h$ and casein rate but the absence a correlation for either SSBM and ESBM (Figure 4a). Again, an opposite relationship was found for the soybean meals using medium obtained from cows at high intake. There was a positive relationship between concentration of TAA and microbial protein, whether measured in the inoculum before or after preincubation, or in the in vitro medium at 0 h (Figure 4b). Free AA contents in ruminal fluid appear to be largely cell associated (Broderick and Craig, 1989) and most of the TAA in inocula likely derived from the intracellular free AA pool. Therefore, TAA appear to be an indirect measure of microbial biomass.

\section{SUMMARY AND CONCLUSIONS}

An inhibitor in vitro method was used to estimate rates of protein degradation for casein, SSBM, ESBM, and alfalfa hay from net appearance of $\mathrm{N}$ as $\mathrm{NH}_{3}$ and TAA in ruminal media containing $1.0 \mathrm{~m} M$ HS and 30 $\mathrm{mg} / \mathrm{L}$ of CAP. Preincubation or dialysis of inocula reduced background $\mathrm{NH}_{3}$ and TAA. However, preincubation yielded less variable and more rapid estimates of degradation rates for casein and SSBM, possibly because of increased microbial biomass. Preincubating in
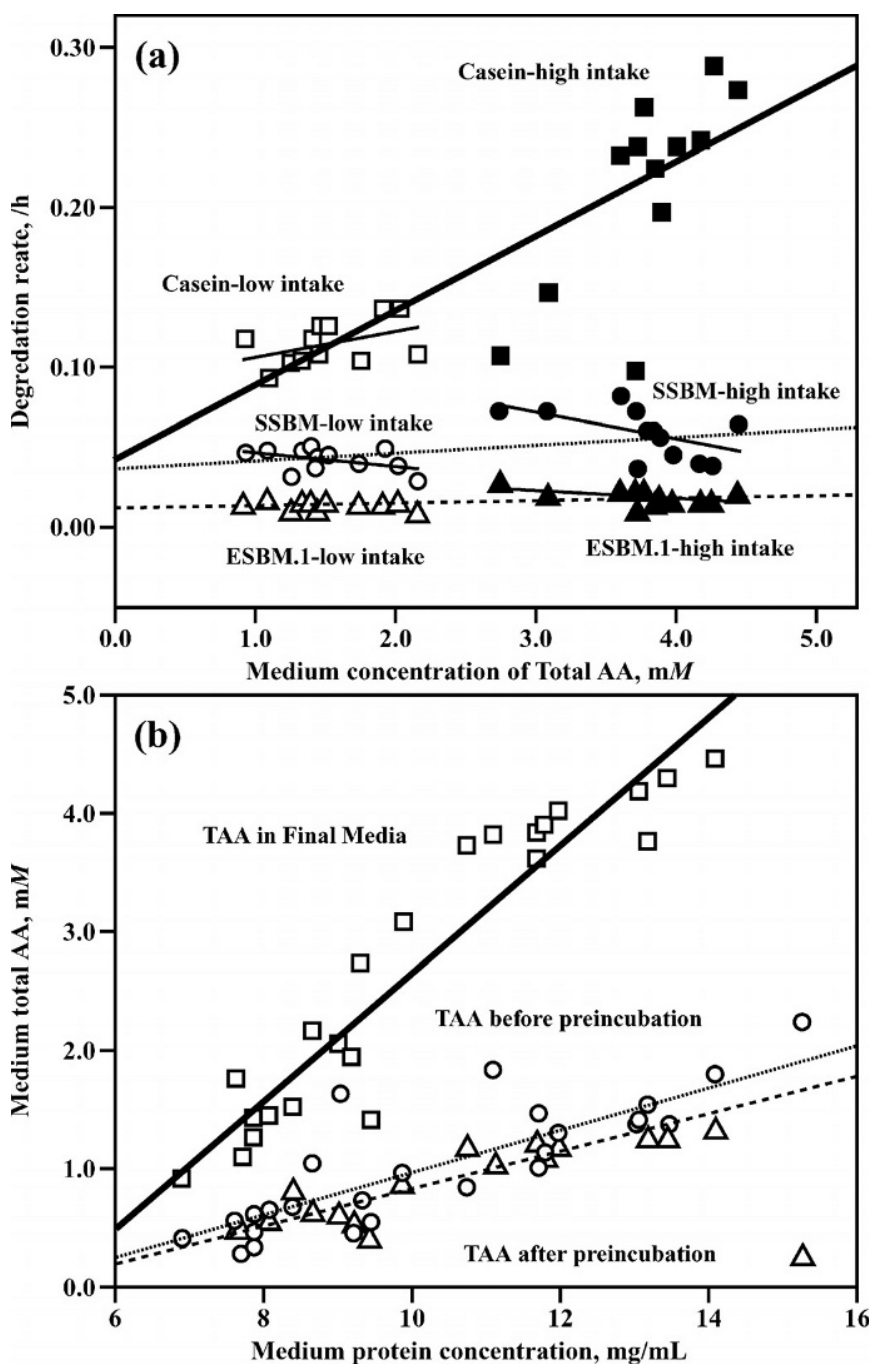

Figure 4. (a) Regressions of degradation rates observed for casein, solvent soybean meal (SSBM), and expeller soybean meal (ESBM.1) on total AA concentrations in final media added at $0 \mathrm{~h}$ to incubations conducted in Sweden using ruminal inocula from nonlactating cows fed at maintenance (open symbols) and from lactating cows fed at about $3 \times$ maintenance (closed symbols). Bold regression lines, for each protein over both levels of feed intake, yielded regressions of: $\mathrm{y}=0.046 \mathrm{x}+0.041\left(\mathrm{r}^{2}=0.716\right)$ for casein; $\mathrm{y}=0.005 \mathrm{x}+0.038\left(\mathrm{r}^{2}=\right.$ $0.167)$ for SSBM; and $\mathrm{y}=0.001 \mathrm{x}+0.014\left(\mathrm{r}^{2}=0.171\right)$ for ESBM.1. Lighter regression lines represent the trends for each protein within each level of feed intake. (b) Regressions on $\mathrm{CP}(\mathrm{N} \times 6.25)$ contents in the final media of total AA concentrations in: 1) ruminal inocula before preincubation $\left.\left(\mathrm{y}=0.179 \mathrm{x} \times 0.823 ; \mathrm{r}^{2}=0.644\right) ; 2\right)$ ruminal inocula after preincubation for $3 \mathrm{~h}$ with added carbohydrates $(\mathrm{y}=$ $\left.0.157 \mathrm{x}-0.727 ; \mathrm{r}^{2}=0.881\right)$; or 3$)$ final media at $0 \mathrm{~h}(\mathrm{y}=0.538 \mathrm{x}-$ $\left.2.728 ; \mathrm{r}^{2}=0.899\right)$.

vitro inoculum may yield more reliable estimates of the rate and extent of ruminal protein degradation. Preincubation with added vitamins, VFA, hemin, and $\mathrm{N}$ had little effect on degradation parameters. Fractionation studies with in vitro inocula indicated that both casein and SSBM were more rapidly degraded by fluid 
than particulate associated microbes. Degradation of ESBM was not affected by inoculum fractionation. Similar rates and extents of protein degradation were obtained for soybean meals and alfalfa when computed from total $\mathrm{N}$ release and from the sum of TAA, quantified using ninhydrin colorimetry or o-phthalaldehyde, plus $\mathrm{NH}_{3}$. However, casein degradation was more rapid when computed from total $\mathrm{N}$ release or when $\mathrm{N}$ present in small peptides was accounted for. Rates also were more rapid using inocula from lactating cows versus that from nonlactating cows consuming one-third as much $\mathrm{NE}_{\mathrm{L}}$. Protein degradation rates were different due to time after feeding: casein rate was more rapid, but SSBM and ESBM rates were slower, using inocula obtained after feeding. These results suggested that degradative activity toward rapidly degraded proteins, such as casein, may be unrelated to ruminal degradation of common feed proteins, such as SSBM and ESBM, that are more slowly degraded.

\section{ACKNOWLEDGMENTS}

The authors thank Håkan Wallin, Anne OdelströmMunter, Lena Linström, Brad Ricker, Mary Becker, and Wendy Radloff for excellent technical assistance and Peter Crump for aiding with statistical analyses.

\section{REFERENCES}

Association of Official Analytical Chemists. 1980. Official Methods of Analysis. 13th ed. AOAC, Washington, DC.

Block, R. J., and K. W. Weiss. 1956. The Amino Acid Handbook. Thomas, Springfield, IL.

Broderick, G. A. 1978. In vitro procedures for estimating rates of ruminal protein degradation and proportions of protein escaping the rumen undegraded. J. Nutr. 108:181-190.

Broderick, G. A. 1987. Determination of protein degradation rates using a rumen in vitro system containing inhibitors of microbial nitrogen metabolism. Br. J. Nutr. 58:463-476.

Broderick, G. A. 1995. Performance of lactating dairy cows fed either alfalfa silage or alfalfa hay as the sole forage. J. Dairy Sci. 78:320-329.

Broderick, G. A., and K. A. Albrecht. 1997. Ruminal in vitro degradation of protein in tannin free and tannin-containing forage legume species. Crop Sci. 37:1884-1891.

Broderick, G. A., and R. C. Cochran. 2000. In vitro and in situ methods for estimating digestibility with reference to protein degradability. Pages 53-86 in Feeding Systems and Feed Evaluation Models, M. K. Theodorou and J. France, ed. CABI Publishing, Wallingford, UK.

Broderick, G. A., and W. M. Craig. 1989. Metabolism of peptides and amino acids during in vitro protein degradation by mixed rumen organisms. J. Dairy Sci. 72:2540-2548.

Broderick, G. A., and J. H. Kang. 1980. Automated simultaneous determination of ammonia and total amino acids in ruminal fluid and in vitro media. J. Dairy Sci. 63:64-75.

Broderick, G. A., D. B. Ricker, and L. S. Driver. 1990. Expeller soybean meal and corn by-products versus solvent soybean meal for lactating dairy cows fed alfalfa silage as sole forage. J. Dairy Sci. 73:453-462.

Broderick, G. A., R. J. Wallace, and N. McKain. 1988. Uptake of small neutral peptides by mixed rumen microorganisms in vitro. J. Sci. Food Agric. 42:109-118.
Carpintero, C. M., A. R. Henderson, and P. McDonald. 1979. The effect of some pretreatments on proteolysis during the ensiling of herbage. Grass Forage Sci. 34:311-321.

Carro, M. D., and E. L. Miller. 1999. Effect of supplementing a fibre basal diet with different nitrogen forms on ruminal fermentation and microbial growth in an in vitro semi-continuous culture system (RUSITEC). Br. J. Nutr. 82:149-157.

Choi, C. W., S. Ahvenjarvi, A. Vanhatalo, V. Toivonen, and P. Huhtanen. 2002. Quantitation of the flow of soluble non-ammonia nitrogen entering the omasal canal of dairy cows fed grass silage based diets. Anim. Feed Sci. Technol. 96:203-220.

Craig, W. M., B. J. Hong, G. A. Broderick, and R. J. Bula. 1984. In vitro inoculum enriched with particle-associated microorganisms for determining rates of fiber digestion and protein degradation. J. Dairy Sci. 67:2902-2909.

Craig, W. M., G. A. Broderick, and D. B. Ricker. 1987. Quantitation of microorganisms associated with the particulate phase of ruminal ingesta. J. Nutr. 117:56-62.

England, M. L., G. A. Broderick, R. D. Shaver, and D. K. Combs. 1997. Comparison of in situ and in vitro techniques for measuring ruminal degradation of animal by-product proteins. J. Dairy Sci. 80:2925-2931.

Faldet, M. A., and L. D. Satter. 1991. Feeding heat-treated full fat soybeans to cows in early lactation. J. Dairy Sci. 74:3047-3054.

Furchtenicht, J. E., and G. A. Broderick. 1987. Effect of inoculum preparation and dietary energy on microbial numbers and rumen protein degradation activity. J. Dairy Sci. 70:1404-1410.

Hall, M. B., and C. Herejk. 2001. Differences in yields of microbial crude protein from in vitro fermentation of carbohydrates. J. Dairy Sci. 84:2486-2493.

Hespell, R. B., and M. P. Bryant. 1981. The genera Butyrivibrio, Succinivibrio, Succinimonas, Lachnospira, and Selenomonas. Pages 14789 in The Procaryotes: A Handbook on Habitats, Isolation and Identification of Bacteria. H. G. Truper, A. Balows and G. Schlegel, eds. Springer-Verlag, New York, NY.

Hristov, A., and G. A. Broderick. 1996. Synthesis of microbial protein in ruminally cannulated cows fed alfalfa silage, alfalfa hay or corn silage. J. Dairy Sci. 79:1627-1637.

Hsu, J. T., and L. D. Satter. 1995. Procedures for measuring the quality of heat-treated soybeans. J. Dairy Sci. 78:1353-1361.

Lines, L. W., and W. P. Weiss. 1996. Use of nitrogen from ammoniated alfalfa hay, urea, soybean meal, and animal protein meal by lactating cows. J. Dairy Sci. 79:1992-1999.

Luchini, N. D., G. A. Broderick, and D. K. Combs. 1996. Preservation of ruminal microorganisms for in vitro determination of ruminal protein degradation. J. Anim. Sci. 74:1134-1143.

Mason, V. C., S. Bech-Andersen, and M. Rudemo. 1979. Hydrolysate preparation for amino-acid determinations in feed constituents. 1. Stability of bound amino-acids to oxidation with performic acid hydrogen peroxide reagents. Z. Tierphysiol. Tierernaehr. Futtermittelkud. 41:226-235.

McDougall, E. I. 1948. Studies on ruminant saliva. I. The composition and output of sheep's saliva. Biochem. J. 43:99-109.

Muscato, T. V., C. J. Sniffen, U. Krishnamoorthy, and P. J. Van Soest. 1983. Amino acid content on noncell and cell wall fractions in feedstuffs. Nitrogen fractions in selected feedstuffs. J. Dairy Sci. 66:2198-2207.

National Research Council. 1996. Nutrient Requirements of Beef Cattle. 7th rev. ed. Natl. Acad. Sci., Washington, DC.

National Research Council. 2001. Nutrient Requirements of Dairy Cattle. 7th rev. ed. Natl. Acad. Sci., Washington, DC.

Peltekova, V. D., and G. A. Broderick. 1996. In vitro ruminal degradation and synthesis of protein on fractions extracted from alfalfa hay and silage. J. Dairy Sci. 79:612-619.

Ranilla, M. J., M. D. Carro, S. Lopez, C. J. Newbold, and R. J. Wallace. 2001. Influence of nitrogen source on the fermentation of fibre from barley straw and sugarbeet pulp by ruminal micro-organisms in vitro. Br. J. Nutr. 86:717-724.

Roth, M. 1971. Fluorescence reaction of amino acids. Anal. Chem. 43: $880-882$.

SAS. 1999-2000. SAS/STAT User's Guide (Release 8.1), SAS Inst., Inc., Cary, NC. 
Schaefer, D. M., C. L. Davis, and M. P. Bryant. 1980. Ammonia saturation constants for predominant species of rumen bacteria. J. Dairy Sci. 63:1248-1263.

Siddons, R. C., and J. Paradine. 1981. Effect of diet on protein degrading activity in the sheep rumen. J. Sci. Food Agric. 32:973-981.

Tremblay, G. F., G. A. Broderick, and S. M. Abrams. 1996. Estimating ruminal protein degradation of roasted soybeans using near infrared reflectance spectroscopy. J. Dairy Sci. 79:276-282.

Van Soest, P. J., J. B. Robertson, and B. A. Lewis. 1991. Methods for dietary fiber, neutral detergent fiber and nonstarch polysac- charides in relation to animal nutrition. J. Dairy Sci. 74:35833597.

Wells, J. E., and J. B. Russell. 1996. Why do many rumen bacteria die and lyse so quickly? J. Dairy Sci. 79:1487-1495.

Waldo, D. R., L. W. Smith, and E. L. Cox. 1972. Model of cellulose disappearance from the rumen. J. Dairy Sci. 55:125-129.

Wallace, R. J., C. Atasoglu, and C. J. Newbold. 1999. Role of peptides in rumen microbial metabolism: Review. Asian-Australasian-J. Anim. Sci. 12:139-147 